\title{
Cooking Fuel Usage in Sub-Saharan Urban Households
}

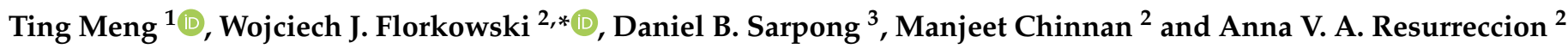 \\ 1 Academy of Global Food Economics and Policy, Beijing Food Safety and Strategy Research Base, \\ College of Economics and Management, China Agricultural University, Beijing 100083, China; \\ tmeng@cau.edu.cn \\ 2 Department of Food Science and Technology, University of Georgia, Griffin, GA 30223-1797, USA; \\ manjeet.chinnan@gmail.com (M.C.); annaresurreccion@gmail.com (A.V.A.R.) \\ 3 Department of Agricultural Economics and Agribusiness, University of Ghana, \\ Legon, Accra P.O. Box LG 25, Ghana; dbsarpong@ug.edu.gh \\ * Correspondence: wojciech@uga.edu; Tel.: +1-770-228-7233
}

check for updates

Citation: Meng, T.; Florkowski, W.J.; Sarpong, D.B.; Chinnan, M.;

Resurreccion, A.V.A. Cooking Fuel Usage in Sub-Saharan Urban Households. Energies 2021, 14, 4629. https://doi.org/10.3390/en14154629

Academic Editors: Xiaolin Wang and Firoz Alam

Received: 21 June 2021

Accepted: 27 July 2021

Published: 30 July 2021

Publisher's Note: MDPI stays neutral with regard to jurisdictional claims in published maps and institutional affiliations.

Copyright: (C) 2021 by the authors. Licensee MDPI, Basel, Switzerland. This article is an open access article distributed under the terms and conditions of the Creative Commons Attribution (CC BY) license (https:/ / creativecommons.org/licenses/by/ $4.0 /)$.

\begin{abstract}
This study models the frequency use of wood, charcoal, liquid gas, electricity, and kerosene in urban households in Ghana and supplements the literature on cooking fuel choices. The modeling is based on survey data collected in several major Ghanaian cities. Survey results indicate that charcoal and liquid gas are frequently used in meal preparation, while the frequency use of firewood, kerosene, and electricity is limited. Frequency use is estimated using the ordered probit technique. Five cooking fuel use equations identify income, socio-demographic characteristics, and location of urban residents as influencing the frequency use. Statistically significant effects measure probability changes in each of the four fuel categories. Income and education increase the probability of often or very often of using liquid gas or electricity to cook. The effect of being employed by the government is similar but less consistent. Age, household size, and marital status are linked to frequency use, but differently affect specific fuels. As the number of children or adults increases in a household, so does the probability of using firewood or charcoal, but this also increases the probability that such households never use liquid gas or electricity for cooking. Regional differences indicate Tamale residents heavily rely on wood and charcoal, and infrequently use liquid gas or electricity. Multiple cooking fuel use behavior may reflect risk aversion to fuel shortages. Increasing incomes and improving education will drive the probability of an increased use of cleaner cooking fuels and decreased use of fuel mixes, benefiting meal preparers' health and the environment.
\end{abstract}

Keywords: cooking fuel choice; survey; ordered probit; probability change; income; location keyword

\section{Introduction}

Daily cooking is indispensable for sustaining millions of people and in many countries cooking fuels represent a major portion of utilized energy. Cooking with modern fuels allows labor and natural resources to be reallocated from fuel collection and production towards income-generating purposes [1,2], while significantly reducing time spent on cooking. In sub-Saharan Africa, $80 \%$ of the population cooks with solid fuels (wood, charcoal, or coal) as compared to 58\% in China and 71\% in India [3]. However, in 2000, $25 \%$ of the population in that part of Africa had access to electricity [4], increasing to $44 \%$ in 2017 [5]. The fast-expanding access to electricity obscures the prevalent use of charcoal in Africa [6]. The number of people depending on solid fuels is expected to substantially increase in sub-Saharan Africa [7]. After Nigeria, Ghana is the second leading charcoal producer [8]. Two common fuels, kerosene and gas (primarily liquid gas), are used by only $7-10 \%[3,9]$ and $4 \%$ of the sub-Saharan population, respectively [3], but in Ghana the use of liquid gas has quickly increased, especially in urban areas [10].

Household members, especially women, spend a large amount of time on fuel collection and cooking using traditional fuels [2,11]. Moreover, high levels of indoor air pollution from burning biomass for cooking pose a health risk [12] and have been listed 
among the top 10 risks damaging human health [13], especially for children. Indoor air pollution from biomass burning is responsible for 4.2 child deaths per 1000 population due to pneumonia [3,14]. About 3.5 million people died prematurely in 2010 due to indoor air pollution resulting from firewood, charcoal, and other biomass combustion [15]. In Ghana, women are the primary meal preparers and they bear a lot of the impact from cooking fuel emissions [16].

Biomass use in cooking appears to result in environmental problems as well. Soil and land degradation are related to the usage of biomass, particularly around densely populated areas. In the dry savannah zone of northern Ghana, charcoal production exacerbates deforestation $[17,18]$. The average annual deforestation in Ghana was estimated at $0.3 \%$ between 2000 and 2015 [19]. Biomass burning contributes to black carbon [20,21] and greenhouse gas (GHG) emissions [3,22]. In 2015, Ghana's population was exposed to toxic particulate matter P2.5 at a level exceeding World Health Organization standards [19]. Both carbon and gas emissions are aggravated by inferior cooking equipment [16] despite progress in that area $[23,24]$. The multiple negative effects of traditional biomass fuel use suggest that it is desirable to accelerate the shift from various types of biomass energy to modern cooking fuels. Mauritius, Republic of South Africa, and Ghana were among the leading countries achieving considerable progress in increasing access to modern energy services for their citizens [25]. In Ghana, electricity demand is growing 6-7\% annually [16] and electricity use for cooking increased in urban areas between 2005 and 2013 [26].

Promotion of modern cooking fuels may not induce the complete abandonment of traditional fuel usage. In fact, a growing body of evidence indicates that using multiple cooking fuels simultaneously is a common phenomenon among households in developing countries (for example, [6]). A predominant cooking fuel combination in Guatemala is firewood and liquid petroleum gas, used by $26 \%$ of urban households, while $52 \%$ of rural households in Vietnam often use wood complemented by straw, and $34 \%$ of households in rural South Africa use both firewood and kerosene for cooking [1]. The effect of factors determining energy choice decisions was quantified in two separate studies conducted in the Republic of South Africa and Burkina Faso [27,28]. The widespread use of multiple fuel types in the developing world was reflected in previous studies' focus on the household's main cooking fuel choice without capturing the behavior of households' multiple fuel frequency use.

The objective of the current study is on cooking fuel usage by modeling the frequency of five alternative fuel types. The focus on frequency of use of different cooking fuels is a novel and supplements previous studies on the choice of cooking fuel filling the gap in empirical research. The study uses data obtained from a survey conducted in urban areas of Ghana. During the survey, households shared details about frequency of the most common fuels used for cooking the main meal of the day, i.e., wood, charcoal, liquid gas, electricity, and kerosene. Cooking fuel use cannot be underestimated because it affects the daily life of virtually all households, but previous research focuses on fuel use by other sectors. The choice of cooking fuel in Ghana and sub-Saharan Africa, by tradition, relates to the choice of the dish prepared for a particular meal because it apparently affects the meal's taste. A household makes a deliberate choice of fuel and selects the one that is most appropriate for preparation of a particular type of food or dish. This study contributes to research on household behavior regarding cooking fuel use and examines fuel usage frequency instead of solely exploring household decisions of cooking fuel choice. Knowledge of frequency supplies detailed and generally missing information about household behavior in cooking fuel use. Additionally, by examining multiple fuel use in cooking in various areas of the country, results of the study recognize the relevance of subtle regional differences in cooking fuel use and possible implications for both human and environmental health. Governments, policy-makers, and NGOs can use results to improve the assessment of different cooking fuel usage in other countries in West Africa. Furthermore, insights gained about household constraints in using modern cooking fuels help to modify energy strategies. Such policies may be more effective by recognizing that, ultimately, the urban 
household transition from traditional biomass cooking fuels to a mix of cooking fuels is conditioned by user, household, and location-specific factors.

The remainder of the paper includes the description of the data and estimation approach in the section Materials and Methods and is followed by the section Results. The latter section includes the description of the summary survey results and the empirical estimation results describe the equations modeling the frequency of using each cooking fuel. Next, the section "Discussion" elaborates on the statistically significant factors influencing the frequency of cooking fuel use, while the last section presents conclusions.

\section{Cooking Fuel Use in the Literature}

Earlier studies have established that socio-demographic factors, situational factors, and psychological factors affect household cooking fuel usage, especially in developing countries. Socio-demographic factors, including age, gender, education, employment status, household type, and location have a significant influence on cooking fuel usage. Education, household wealth and socio-economic status are well recognized predictors of adoption and sustained use of clean modern fuels [29]. Sharma (2018) [30] lists the determinants of household cooking energy demand as literacy status, landholding size and household size. Cleaner energy is more likely to be used in households where the head of the family has a higher level of education and income, whereas larger households and households with a higher proportion of dependent members, and an older person or female as head of the family, are less likely to use cleaner energy [31]. Lower education levels of the household and private house ownership are linked to the consumption of fuels such as firewood and kerosene [32]. Moreover, residence in urban areas positively affects choice of liquefied petroleum-gas as compared to traditional fuels [33].

Current situational factors such as presence and availability of cleaner and modern energy alternatives, and associated financial supports increase the adoption of cleaner energy. The presence of alternative fuels that are less polluting and more convenient increases the adoption of clean energy [30]. Access to renewable energy leads to a preferred selection of modern, clean fuels [32]. Availability of electricity positively affects choice of liquefied petroleum-gas as compared to traditional fuels [33]. Moreover, the lack of modern energy technology options and the lack of financing and other support decrease the use of clean energy [34].

Finally, psychological factors (e.g., values, motivation, vulnerability) also influence cooking fuel adoption among households. The lack of motivation and the pressure for switching over to cleaner facilities has impeded the transition towards clean cooking equipment [34]. Perception of benefits of "easy cooking" and "saving time and money" promotes the adoption of biogas [35]. Moreover, attitude toward technology and awareness of the health risks of using traditional cooking fuel change energy adoption behavior [36].

The choice of one cooking fuel does not completely eliminate the dependence on the use of other cooking fuels, resulting the use of multiple fuels [37]. Consequently, the important question is what factors influence the frequency of a given cooking fuel, which is the focus of the current study.

\section{Materials and Methods}

Household behavior regarding cooking fuel use in sub-Saharan Africa differs from fuel use in developed countries. Cultural preferences and lifestyles condition the choice of cooking fuel in daily main meal preparation. It is not unusual for a household to own several cooking stoves, each using a different type of fuel. The frequency of a cooking method and the concomitant cooking fuel choice is driven by the frequency of preparing a specific type of a dish. Additionally, disruptions in the supply of modern fuel types encourage having an alternative cooking stove using other fuels to assure food preparation. Multigenerational households where more than one person participates in cooking may have multiple cooking stoves and fuels meeting preferences and skills of various preparers. Thus, the frequency of cooking fuel use suggests the empirical approach that permits 
modeling the frequency of fuel use. The estimation of cooking fuel choice requires data that are not readily available and the current study applies data gathered through a household survey.

\subsection{Data}

The study uses survey data collected in three large cities in Ghana (Accra, Takoradi, and Tamale) in 2011. The surveyed cities are located in the northern and southern parts of the country and in two different ecological zones, i.e., Takoradi and Accra are located in the coastal zone of southern Ghana, and Tamale, capital of the Northern Region, is located in the dry savannah zone. The share of urban population in Ghana exceeds 50\% [38]. Cost limitations and logistics as well as the concentrated use of cooking fuel restricted the scope of the survey to major urban areas.

The drafted structured questionnaire consisted of sections collecting information needed for the study. Questions probed respondents about their usage frequency of the most common cooking fuels, i.e., wood, charcoal, liquid gas, electricity, and kerosene. The reported usage frequency of each fuel was measured on a scale from one to four with an increasing number indicating its more frequent use (i.e., $1=$ not used at all, $2=$ seldom, $3=$ often, $4=$ used very often). A separate set of questions also probed commonly sought (in national census surveys) personal information and household characteristics such as age, gender, occupation, income, and household composition.

Trained enumerators using a pre-tested questionnaire conducted the face-to-face interviews. Among residents of Tamale, enumerators involved in the national statistical panel data collection, who were fluent in Dagbani, a regional language, conducted the interviews. Among residents of Takoradi and Accra, the majority speaks English and the interviews were mostly conducted in that language. Neither language nor the formulation of questions in the survey instrument posed difficulties to respondents during the pilot stage of the survey. A typical interview lasted about 35-45 min. Following the collection of the questionnaires, the information was entered into the dataset. A total of 1010 households were participating in the survey. However, the number of fully completed questionnaires was less and varied with regard to the questions about the five cooking fuels. As a result, the estimation of each equation of cooking fuel use frequency differed and ranged from 1006 in the case of charcoal to 940 for the use of kerosene.

\subsection{Estimation Approach}

The study applies the ordered probit regression model to investigate how the sociodemographic factors affect an urban household's usage frequency of certain cooking fuels. Social science research commonly uses ordinal numbers to measure and quantify phenomena transformed into variables. The ordered probit model is common in empirical studies applying the ordered categorical variable. In the basic framework of the regression model (Equation (1)) $Y^{*}$ is the latent variable behind the fuel use frequency, $X$ denotes the selected explanatory variable vector, $B$ is the coefficient vector, and $e$ is the error term, which is assumed to follow normal distribution:

$$
Y^{*}=X B+e
$$

where $Y^{*}$ is the latent variable depicting the frequency of using a specific cooking fuel, $X$ is the vector of the explanatory variables, including in this study socioeconomic, demographic, and location features, $B$ is the vector of the coefficients to be estimated, and $e$ is a vector of error terms.

The relation between the latent variable $Y^{*}$ and the dependent variable $Y$ is defined in Equation (2):

$$
Y=i \text {, if } \text { cut }_{i-1}<Y^{*}<\text { cut }_{i} \text {, where } i=1,2,3,4
$$

when the latent variable is between particular cut points [39] and $i$ indicates one of the four categories of using the cooking fuel associated with the use of the ordered probit, i.e., not 
at all, seldom, often, and very often (see also the description in the Section 3.1 Data). The dependent variable is equal to a certain ordinal level, where $C u t^{\prime}$ s are parameters to be estimated assuming $\mathrm{Cut}_{i-1}<\mathrm{Cut}$ (because of convenience in the estimated model, $\mathrm{Cut}$ and $\mathrm{Cut}_{4}$ are used to denote negative infinite and infinite) [39]. The probability of fuel usage frequencies can be expressed as the difference between two Cumulative Distribution Functions (CDFs) of normal distribution (Equation (3)):

$$
\begin{gathered}
\operatorname{Prob}(Y=i)=\operatorname{Prob}\left(\text { cut }_{i-1}<Y^{*}<c u t_{i}\right) \\
=\operatorname{Prob}\left(\text { cut }_{i-1}-X B<e<c u t_{i}-X B\right) \\
=F\left(\text { cut }_{i}-X B\right)-F\left(c_{i-1}-X B\right)
\end{gathered}
$$

where $F()$ is the CDFs of normal distribution, and Cut's and $B$ are coefficients to be estimated.

In each equation, the likelihood function of the empirical model (Equation (4)) is the product of all possible probabilities with the indicator variable $d$ as corresponding power, and $N$ is the total sample size,

Likelihood $=\prod_{j} \prod_{i} \operatorname{Prob}(Y=i)^{d(Y=i)}$ where $j=1,2, \ldots, N, d=1$ if $Y=i ; d=0$, otherwise

In Equation (4), $j$ indicates the $j$ th respondent, $i$ indicates the $i$ th category of fuel usage frequency referring to a specific cooking fuel, and $d=1$ only if a certain category is selected. For example, if there are $n 1, n 2, n 3$, and n4 respondents who choose the use of liquid gas with the frequency "not at all", "seldom", "often", and "very often", then the likelihood function for the specific case in this study is:

$$
\text { Likelihood }=[\operatorname{Prob}(Y=1)]^{n 1}[\operatorname{Prob}(Y=2)]^{n 2}[\operatorname{Prob}(Y=3)]^{n 3}[\operatorname{Prob}(Y=4)]^{n 4} \text {. }
$$

The ordered probit coefficients lack direct interpretation that generates practical knowledge until the coefficients are converted into probability changes. In particular, probability change measures an increase or a decrease of using one of the five cooking fuels with the frequency captured by the four-step scale. The conversion allows measuring specific probability changes in response to changes in the explanatory variables.

The explanatory variables are shaped by the unobservable preferences reflected in identifiable socio-demographic characteristics. Thus, both consumer theory and previous studies about cooking fuel choices guide the explanatory variable selection in the current study. Evidence shows that selected socioeconomic and demographic factors significantly affect household cooking fuel usage. Several studies closely link income growth with changing household fuels $[28,40,41]$. Other studies indicate that households of respondents with high educational attainment levels tend to use modern fuels which offer significant time savings, especially for women [1]. Demographic characteristics are also relevant because the household energy type selection can be captured by its size and composition $[1,28]$. Finally, given that Ghana encompasses several different ecozones, the location of a household in a particular urban area is explicitly included by adding a place indicator.

\section{Results}

\subsection{Survey Results}

The usage frequencies regarding each cooking fuel type are displayed on Figure 1. Regarding traditional biomass fuels, only about $20.9 \%$ of the surveyed households still use wood, and among the users of wood for fuel, one half of them seldom use wood only. Wood generates smoke and, compared to other cooking fuels considered in the study, is inconvenient to handle. About $86.6 \%$ of the surveyed households use charcoal seldom, often, or very often. The popularity of charcoal among urban sub-Saharan African households has been estimated at above $80 \%$ [42]. Charcoal is characterized by high energy content and clean burning as compared to wood. The use of charcoal as the primary fuel for cooking among urban households in Ghana has been estimated at about 53\% [43]. In Tamale, charcoal has been reported as the main cooking fuel for about $50 \%$ of the residents 
and $45 \%$ in Greater Accra, [44]. The current study also reports the relative use, and about $60 \%$ of respondents indicate they use charcoal for cooking their main meal of the day often or very often (Table 1$)$.

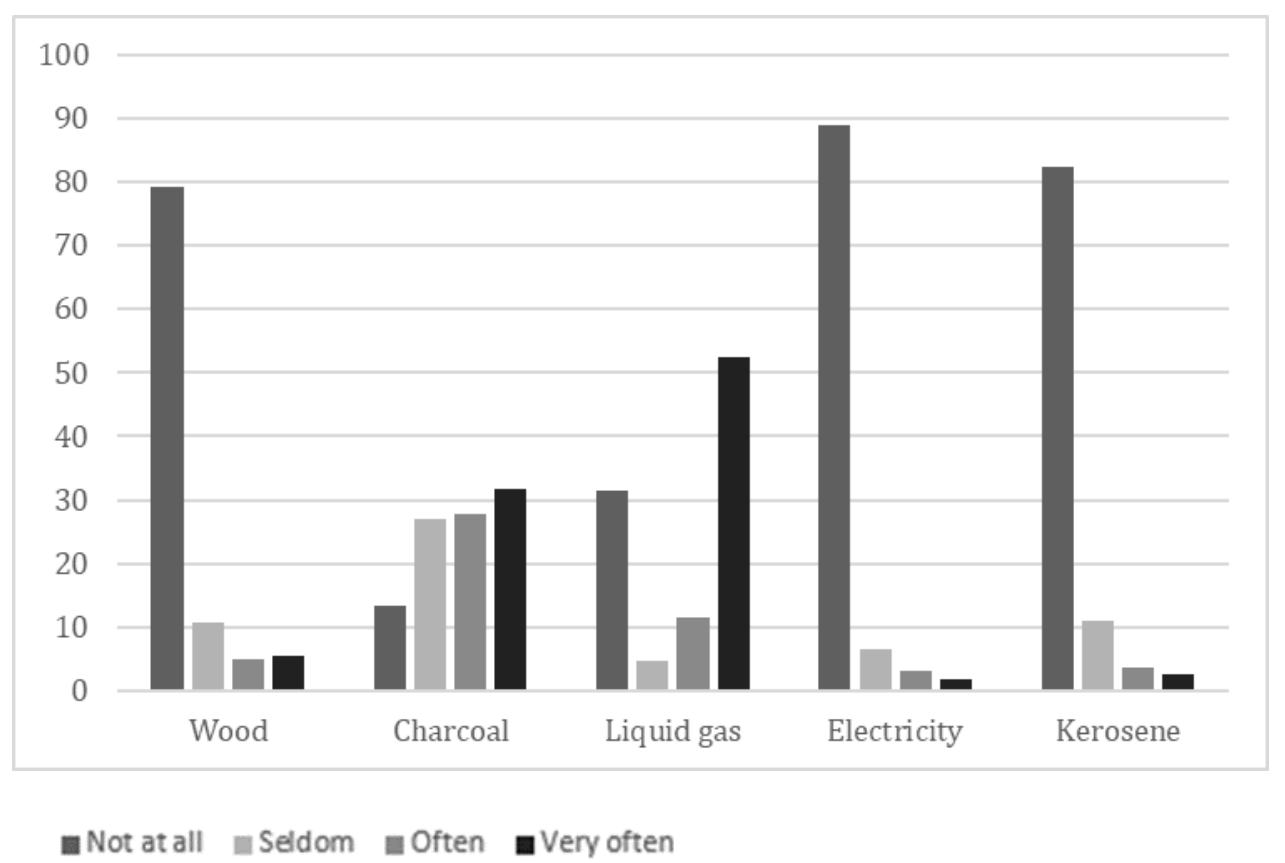

Figure 1. The use of five fuels in cooking the main meal of the day by four frequency categories in urban households in Ghana, in\% $(n=956)$. Source: Summary responses from the household survey.

Table 1. Descriptive statistics of variables included in the empirical model.

\begin{tabular}{|c|c|c|c|}
\hline Variable Name & Variable Description/Units of Measurement & Mean & Std Dev \\
\hline \multicolumn{4}{|l|}{ Dependent variables ${ }^{1}$} \\
\hline Frequency of cooking with wood & $\begin{array}{l}\text { How often do you use wood to cook your main meal of the } \\
\text { day? } 1=\text { not at all; } 2=\text { seldom; } 3=\text { often; } 4=\text { very often }\end{array}$ & 1.365 & 0.807 \\
\hline Frequency of cooking with charcoal & $\begin{array}{l}\text { How often do you use charcoal to cook your main meal of } \\
\text { the day? } 1=\text { not at all; } 2=\text { seldom; } 3=\text { often; } 4=\text { very often }\end{array}$ & 2.779 & 1.037 \\
\hline Frequency of cooking with liquid gas & $\begin{array}{l}\text { How often do you use liquid gas to cook your main meal of } \\
\text { the day? } 1=\text { not at all; } 2=\text { seldom; } 3=\text { often; } 4=\text { very often }\end{array}$ & 2.848 & 1.345 \\
\hline Frequency of cooking with electricity & $\begin{array}{l}\text { How often do you use electricity to cook your main meal of } \\
\text { the day? } 1=\text { not at all; } 2=\text { seldom; } 3=\text { often; } 4=\text { very often }\end{array}$ & 1.175 & 0.553 \\
\hline Frequency of cooking with kerosene & $\begin{array}{l}\text { How often do you use kerosene to cook your main meal of } \\
\text { the day? } 1=\text { not at all; } 2=\text { seldom; } 3=\text { often; } 4=\text { very often }\end{array}$ & 1.260 & 0.649 \\
\hline \multicolumn{4}{|l|}{ Independent variables } \\
\hline & Demographic factors & & \\
\hline Married & $=1$ if $\mathrm{a}$ respondent is married & 0.753 & 0.431 \\
\hline Age & Actual age in years & 39.222 & 10.656 \\
\hline Children & Number of household members between $13-18$ years old & 0.983 & 1.205 \\
\hline Adult & Number of household members between $19-60$ years old & 2.087 & 1.751 \\
\hline Elder & $\begin{array}{l}\text { Number of household members } 61 \text { years old or older } \\
\text { Socio-economic factors }\end{array}$ & 0.153 & 0.505 \\
\hline Income & $\begin{array}{l}\text { Household income in the month preceding the survey/in } \\
\text { Ghanaian cedis }\end{array}$ & 646.070 & 785.081 \\
\hline Self employed & $=1$ if a respondent is self-employed & 0.642 & 0.480 \\
\hline Government or civil employed & $=1$ if a respondent is gov/civil employee & 0.243 & 0.429 \\
\hline Secondary Education & $\begin{array}{l}=1 \text { if a respondent has a secondary education (including } \\
\text { Senior high/GCE O-A level, Vocational school, Technical } \\
\text { school, Teacher training) }\end{array}$ & 0.382 & 0.486 \\
\hline
\end{tabular}


Table 1. Cont.

\begin{tabular}{|c|c|c|c|}
\hline Variable Name & Variable Description/Units of Measurement & Mean & Std Dev \\
\hline College Education & $\begin{array}{l}=1 \text { if a respondent has a college education (including } \\
\text { Senior high/GCE O-A level, Vocational school, Technical } \\
\text { school, Teacher training, University, or postgraduate) } \\
\text { Location }\end{array}$ & 0.134 & 0.340 \\
\hline Tamale & $=1$ if a household is in Tamale & 0.186 & 0.389 \\
\hline Takoradi & $=1$ if a household is in Takoradi & 0.208 & 0.406 \\
\hline
\end{tabular}

${ }^{1}$ See the distribution of frequency use in Table 2

Table 2. The use of five fuels in cooking the main meal of the day by four frequency categories in urban households in Ghana, in \%.

\begin{tabular}{|c|c|c|c|c|}
\hline Fuel & Not at All & Seldom & Often & Very Often \\
\hline \multicolumn{5}{|l|}{ Tamale } \\
\hline Wood $(n=179)$ & 54.75 & 17.88 & 9.50 & 17.88 \\
\hline Charcoal $(n=185)$ & 8.65 & 20.00 & 23.78 & 47.57 \\
\hline Liquid gas $(n=177)$ & 61.02 & 3.95 & 6.21 & 28.81 \\
\hline Electricity $(n=172)$ & 98.26 & 0 & 1.16 & 0.58 \\
\hline Kerosene $(n=172)$ & 89.53 & 6.98 & 0.58 & 2.91 \\
\hline \multicolumn{5}{|l|}{ Takoradi } \\
\hline Wood $(n=207)$ & 86.47 & 8.21 & 2.90 & 2.42 \\
\hline Charcoal $(n=210)$ & 13.81 & 33.81 & 17.62 & 34.76 \\
\hline Liquid gas $(n=209)$ & 25.84 & 7.18 & 7.18 & 59.81 \\
\hline Electricity $(n=207)$ & 89.86 & 4.83 & 3.38 & 1.93 \\
\hline Kerosene $(n=206)$ & 80.58 & 14.56 & 2.91 & 1.94 \\
\hline \multicolumn{5}{|l|}{ Accra } \\
\hline Wood $(n=570)$ & 86.32 & 8.77 & 3.33 & 1.58 \\
\hline Charcoal $(n=608)$ & 14.80 & 28.29 & 32.57 & 24.34 \\
\hline Liquid gas $(n=603)$ & 22.89 & 4.15 & 13.93 & 59.04 \\
\hline Electricity $(n=562)$ & 84.34 & 9.79 & 3.74 & 2.14 \\
\hline Kerosene $(n=562)$ & 81.14 & 11.39 & 4.8 & 2.67 \\
\hline
\end{tabular}

About two thirds of the respondents, $63.9 \%$, use liquid gas often or very often for cooking the main meal of the day (Table 1). This share is much higher than the national average, which indicates $9.5 \%$ of all households used liquid gas for cooking in 2008 . The expansion of liquid gas use among urban households may reflect the transition to modern cooking fuels as part of Ghana's energy policy and reflects the government subsidy program (despite periodic shortages in the liquid gas supply).

According to the survey results, only a small number of households cook with kerosene or electricity, despite how easy and safe it is to use either cooking fuel (though relative prices favor kerosene use over electricity). Electricity is used by about $11.2 \%$ and kerosene by $17.3 \%$ of respondents at least occasionally, and the shares correspond to $14 \%$ for electricity and $20 \%$ for petroleum in the country's total annual energy consumption. Among responding users of either of the two fuel types, only $1.7 \%$ and $2.6 \%$ report using kerosene or electricity, respectively, very often to cook the main meal of the day.

The survey results are summed by displaying the definition, measurement units, and descriptive statistics (the mean and standard deviation) of factors used as variables in the empirical analysis (Table 2). In the sample, $60.6 \%$ of survey participants are from Accra, $20.8 \%$ from Takoradi, and the remaining $18.6 \%$ from Tamale. The average respondent is 39.2 years old. Among surveyed households, three out of four are households of married respondents. Married households are more likely to cook meals because cooking is expected as a part of division of tasks in a household. In addition, the typical household has one teenage household member (between 13 and 18 years old), two adult members (between 19 and 60 years old), and 0.15 elder members (more than 61 years old). The mean household income in the month preceding the survey is 646.1 cedi (USD $1=1.49989$ 
Ghanaian cedi, 1 January 2011 [34]). In terms of employment status among respondents, $64.2 \%$ report being self-employed, $24.3 \%$ are government or civil employees, and $11.5 \%$ are either not employed, students, or retired. In terms of educational attainment level, 38.2\% of respondents have a secondary education and $13.4 \%$ have a college education.

In addition to the statistics summary for the entire sample, consumer profiles linked to each cooking fuel are provided in Table 3. Because the use of multiple cooking fuels is a common phenomenon among households and the focus on the frequency of use in the current study, the described consumer profiles associated with the use of each cooking fuel refer to the frequency categories "often" or "very often". The frequent use of firewood in cooking characterizes households that tend to be larger, having more children and adults, including elderly members (Table 3). Additionally, frequent users of firewood seldom have a college education, their households report lower incomes, and are more likely to be located in Tamale.

Table 3. Consumer profiles based on the survey results associated with the frequency use of each cooking fuel "often" or "very often".

\begin{tabular}{|c|c|c|c|c|c|}
\hline Characteristic & Wood & Charcoal & Liquid Gas & Electricity & Kerosene \\
\hline \multicolumn{6}{|l|}{ Demographic Factors } \\
\hline Married & 0.79 & 0.71 & 0.79 & 0.84 & 0.76 \\
\hline Age & 43.05 & 39.34 & 39.18 & 43.69 & 42.70 \\
\hline Children & 1.51 & 1.03 & 0.90 & 1.22 & 1.14 \\
\hline Adult & 2.74 & 2.17 & 2.05 & 2.61 & 2.50 \\
\hline Elder & 0.40 & 0.13 & 0.13 & 1.15 & 0.19 \\
\hline \multicolumn{6}{|l|}{ Socio-economic factors } \\
\hline Income & 617.07 & 432.93 & 845.99 & 1116.86 & 896.47 \\
\hline Self employed & 0.65 & 0.74 & 0.57 & 0.60 & 0.69 \\
\hline Government employed & 0.22 & 0.10 & 0.34 & 0.29 & 0.20 \\
\hline Secondary Education & 0.38 & 0.31 & 0.45 & 0.43 & 0.37 \\
\hline College Education & 0.03 & 0.03 & 0.20 & 0.13 & 0.06 \\
\hline \multicolumn{6}{|l|}{ Location } \\
\hline Tamale & 0.41 & 0.29 & 0.11 & 0.20 & 0.22 \\
\hline Takoradi & 0.08 & 0.23 & 0.23 & 0.08 & 0.09 \\
\hline $\mathrm{N}$ & 100 & 316 & 553 & 86 & 94 \\
\hline
\end{tabular}

Households reported using charcoal have the lowest average income and are likely located in Tamale or Takoradi as compared to households using other cooking fuels (Table 3). Respondents from those households are likely self-employee, seldom include government employees, or have college education. In addition, respondents using liquid gas "often" or "very often" are, on average, the youngest and have the smallest number of adults and children as compared to the frequent users of other cooking fuels. The respondents from such households are more likely to be college-educated and employed by the government as compared to households using often other types of cooking fuels.

Households using electricity "often" or "very often" are among those with the highest incomes, their average age is the highest, and the largest number of the elderly. Respondents from those households tend to be well educated, and many of them have a secondary or college education and many are employed by the government (Table 3). Households using kerosene to cook "often" or "very often" have incomes higher than users of all other fuels except electricity. Additionally, those households are relatively large, tend to have older members, and include a sizable share of Tamale respondents. Those respondents likely represent the self-employed and those with a secondary education (Table 3).

\subsection{Empirical Model Estimation Results}

Estimation results of modeling the frequency use of the five cooking fuels are reported in Table 4. The system of equations performs well, as indicated by the likelihood test value significant at $p<0.0001$. The need for practical interpretation of results required 
that the estimated ordered-probit coefficient be converted into a change in probability in the specific fuel frequency use in response to a unit change in an explanatory variable. Figure 2a-e show the probability changes for each frequency category, i.e., not using the specific cooking fuel at all, using it seldom, often, or very often. Because the changes in probability are of primary interest in learning about the factors relevant to various cooking fuel use frequency, the description of the results focuses only on the marginal effects (or effects in the case of binary explanatory variables) that are statistically significant.

Table 4. Ordered probit estimation results of the cooking fuel use frequency in urban households of Ghana.

\begin{tabular}{|c|c|c|c|c|c|}
\hline Variable Name & $\begin{array}{c}\text { Wood } \\
n=956\end{array}$ & $\begin{array}{c}\text { Charcoal } \\
n=1003\end{array}$ & $\begin{array}{l}\text { Liquid Gas } \\
\quad n=989\end{array}$ & $\begin{array}{c}\text { Electricity } \\
n=941\end{array}$ & $\begin{array}{c}\text { Kerosene } \\
n=940\end{array}$ \\
\hline \multicolumn{6}{|c|}{ Demographic factors } \\
\hline \multirow{2}{*}{ Married } & 0.1895 & -0.0260 & $0.2432 * *$ & $0.3993^{* * *}$ & -0.1523 \\
\hline & $(0.1244)$ & $(0.0831)$ & $(0.0952)$ & $(0.1470)$ & $(0.1113)$ \\
\hline \multirow{2}{*}{ Age } & 0.0042 & 0.0013 & -0.0013 & $0.0117 * *$ & $0.0094 *$ \\
\hline & $(0.0050)$ & $(0.0036)$ & $(0.0041)$ & $(0.0058)$ & $(0.0048)$ \\
\hline \multirow{2}{*}{ Children } & $0.1188^{* * *}$ & 0.0458 & -0.0356 & $-0.1171^{* *}$ & 0.0090 \\
\hline & $(0.0396)$ & $(0.0306)$ & $(0.0351)$ & $(0.0591)$ & $(0.0410)$ \\
\hline \multirow{2}{*}{ Adult } & $0.1782 * * *$ & $0.0434 * *$ & -0.0406 & 0.0609 & $0.0900^{* * *}$ \\
\hline & $(0.0279)$ & $(0.0218)$ & $(0.0265)$ & $(0.0384)$ & $(0.0280)$ \\
\hline \multirow{3}{*}{ Elder } & $0.3274^{* * *}$ & -0.0312 & -0.0876 & $-0.3248^{* *}$ & -0.0701 \\
\hline & $(0.0900)$ & $(0.0685)$ & $(0.0811)$ & $(0.1637)$ & $(0.1039)$ \\
\hline & \multicolumn{5}{|c|}{ Socio-economic factors } \\
\hline \multirow{2}{*}{ Income(100 cedi) } & $-0.0179 * *$ & $-0.01352^{* * *}$ & $0.07495^{* * *}$ & $0.0126 *$ & $0.01137 *$ \\
\hline & $(0.0082)$ & $(0.0050)$ & $(0.0111)$ & $(0.0072)$ & $(0.0066)$ \\
\hline \multirow{2}{*}{ Employ_self } & -0.1225 & -0.1662 & 0.0022 & $-0.6144^{* * *}$ & -0.2352 \\
\hline & $(0.1414)$ & $(0.1140)$ & $(0.1288)$ & $(0.1704)$ & $(0.1441)$ \\
\hline \multirow{2}{*}{ Employ_gov } & $-0.4879 * * *$ & $-0.4936^{* * *}$ & $0.5376^{* * *}$ & $-0.3169 *$ & -0.0797 \\
\hline & (0.1999) & $(0.1335)$ & $(0.1571)$ & $(0.1921)$ & $(0.1749)$ \\
\hline \multirow{2}{*}{ Educ_sec } & $-0.3897^{* * *}$ & $-0.2873^{* * *}$ & $0.5085^{* * *}$ & $0.4430 * * *$ & -0.1294 \\
\hline & $(0.1196)$ & $(0.0816)$ & $(0.0927)$ & $(0.1426)$ & $(0.1127)$ \\
\hline \multirow{3}{*}{ Educ_col } & $-0.9952^{* * *}$ & $-0.7488^{* * *}$ & $0.5666^{* * *}$ & $0.8895^{* * *}$ & $-0.4550^{* *}$ \\
\hline & $(0.2760)$ & $(0.1306)$ & $(0.1652)$ & $(0.1897)$ & $(0.1962)$ \\
\hline & & & Location & & \\
\hline \multirow{2}{*}{ Tamale } & $0.7463^{* * *}$ & $0.3226^{* * *}$ & $-0.6749^{* * *}$ & $-0.9639^{* * *}$ & $-0.3922 * * *$ \\
\hline & $(0.1292)$ & $(0.1028)$ & $(0.1229)$ & $(0.2555)$ & $(0.1522)$ \\
\hline \multirow{3}{*}{ Takoradi } & -0.1196 & 0.0343 & 0.0666 & -0.1854 & -0.0315 \\
\hline & $(0.1435)$ & $(0.0930)$ & $(0.1081)$ & $(0.1482)$ & $(0.1262)$ \\
\hline & & & Parameters & & \\
\hline \multirow{2}{*}{ Cut1 } & 1.4452 & -1.5130 & 0.1049 & 1.8263 & 1.1277 \\
\hline & $(0.2704)$ & $(0.2010)$ & $(0.2250)$ & $(0.3134)$ & $(0.2644)$ \\
\hline \multirow{2}{*}{ Cut2 } & 2.0867 & -0.5343 & 0.2783 & 2.3704 & 1.7650 \\
\hline & $(0.2761)$ & $(0.1983)$ & $(0.2253)$ & $(0.3187)$ & $(0.2686)$ \\
\hline \multirow{2}{*}{ Cut3 } & 2.5563 & 0.2612 & 0.6420 & 2.8728 & 2.185371 \\
\hline & $(0.2841)$ & $(0.1970)$ & $(0.2258)$ & $(0.2873)$ & $(0.2739)$ \\
\hline Log Likelihood & -532.60 & -1265.23 & -914.25 & -391.37 & -559.06 \\
\hline Likelihood test & 260.20 & 167.19 & 316.52 & 118.00 & 43.89 \\
\hline ( $p$-value) with DF $=12$ & $(<0.001)$ & $(<0.001)$ & $(<0.001)$ & $(<0.001)$ & $(<0.001)$ \\
\hline
\end{tabular}

Note: Standard errors are in parentheses. ${ }^{*}$ indicates the significance at $10 \%$ level. ${ }^{* *}$ indicates the significance at $5 \%$ level. ${ }^{* * *}$ indicates the significance at $1 \%$ level.

\subsubsection{Wood}

The marginal effects of using wood as a cooking fuel (Figure 2a) show that eight factors significantly influenced wood use frequency. Each additional teenage child in the household lowered the probability of never using wood by $2.7 \%$. Such an addition increased the use of firewood, but with decreasing effect. One more teenager raised the infrequent use of firewood by $1.7 \%$, but the effect was negligible for more frequent use categories. A similar pattern of probability changes on the use of wood for cooking was 
established when the number of adults aged 19-60 and elderly (61 years old or older) increases. Adding one person in each age group increased the "seldom" use of wood by $2.4 \%$ and $4.3 \%$, respectively (Figure $2 a$ ).

Increasing income raises the probability of "never using" wood in cooking and lowers the probability of using it with any of the other three frequency categories (Figure 2, panel a), but the induced change is very small. Only a substantial income increase could be expected to lower the use of firewood. Being a government employee increased the probability of never using wood by $9.4 \%$ and lowered the frequency probability associated with the "seldom", "often", and "very often" category by $5.8 \%, 2.2 \%$, and $1.4 \%$, respectively. The effect of education as compared to those without formal or only elementary education consistently was associated with the increasing probability of never using wood for cooking the main meal or increased probability of using it with any frequency. The probability changes generally increased for all categories as the education level increased (Figure 2a) and increased the probability of never using wood by $14.8 \%$ among the college educated.

The effects of location showed that residents of Tamale had a $20.7 \%$ lower probability than Accra residents of never using wood as cooking fuel. Tamale respondents had a higher probability of using wood for cooking than Accra residents and it ranged from $10.6 \%$ for seldom use to $4.7 \%$ for very often use (Figure $2 \mathrm{a}$ ).

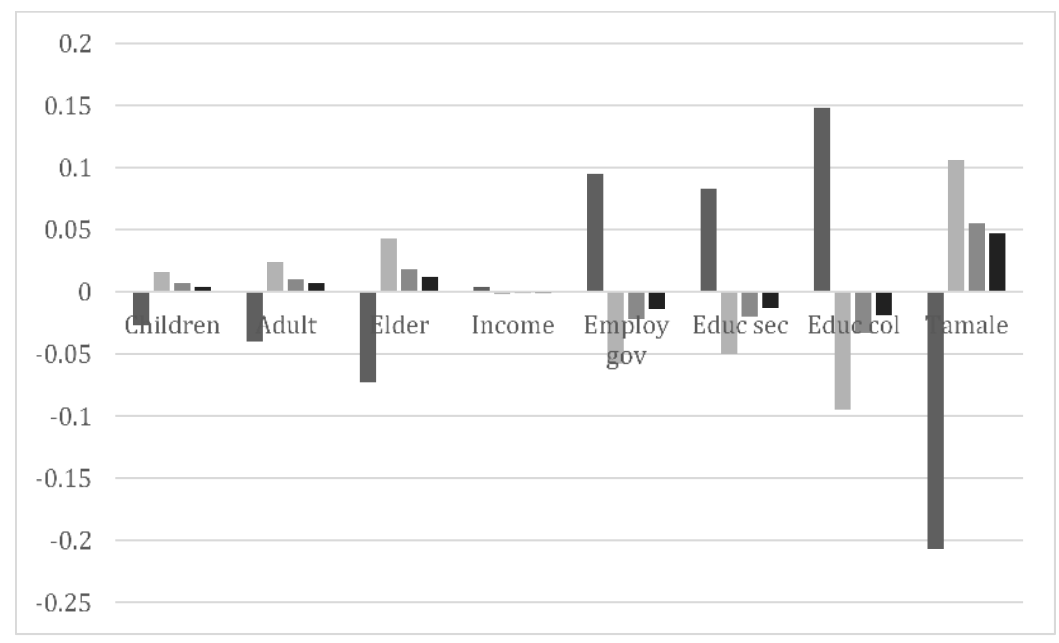

- Not at all $\quad$ Seldom $\quad$ Often $\quad$ Very often

(a) fuel wood

Figure 2. Cont. 


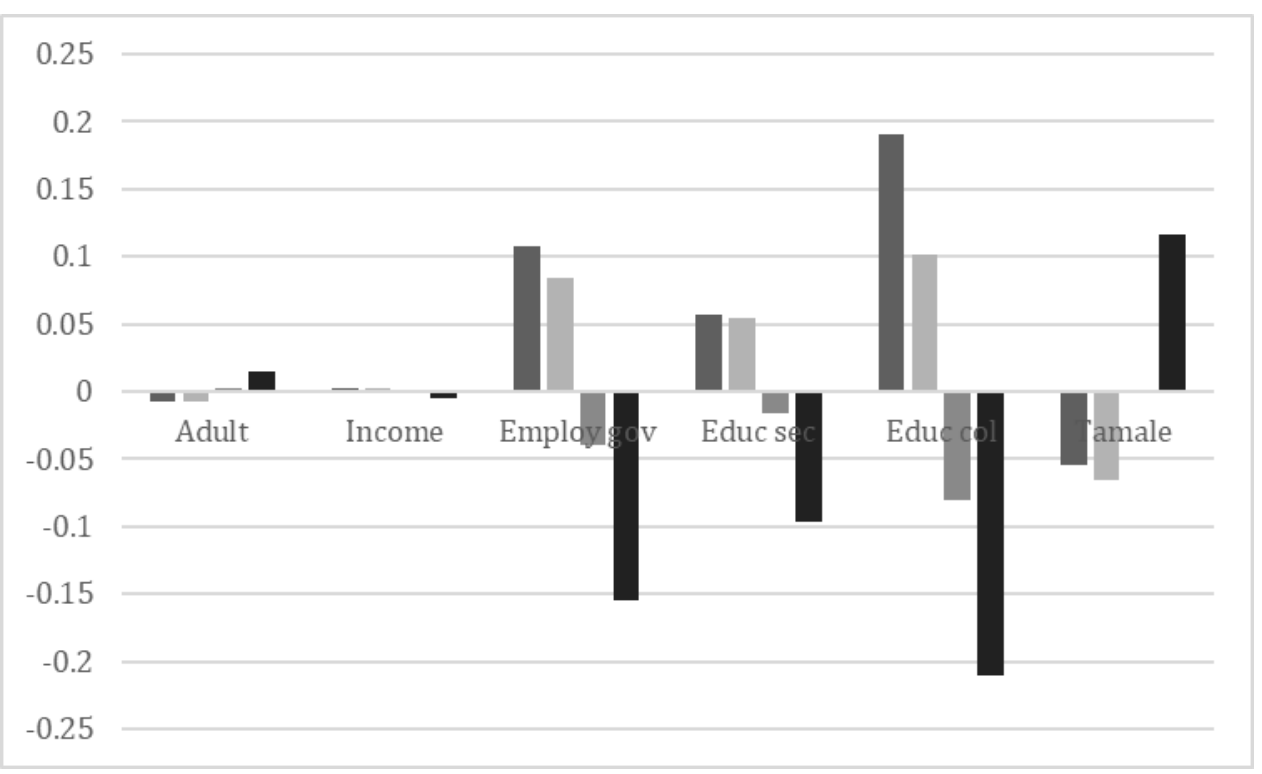

- Not at all $\square$ Seldom $\square$ Often Very often

(b) charcoal frequency use

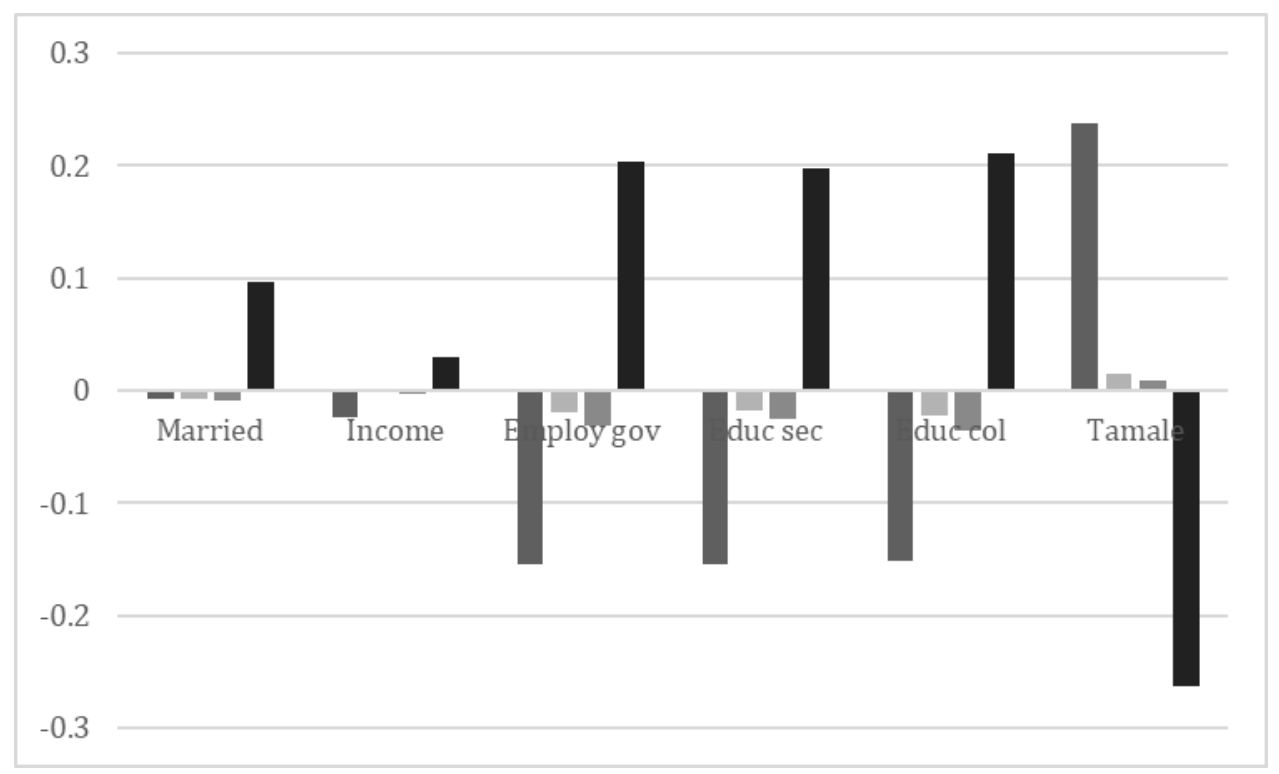

घot at all $\square$ Seldom $\quad$ Often $\quad$ Very often

(c) liquid gas frequency use

Figure 2. Cont. 


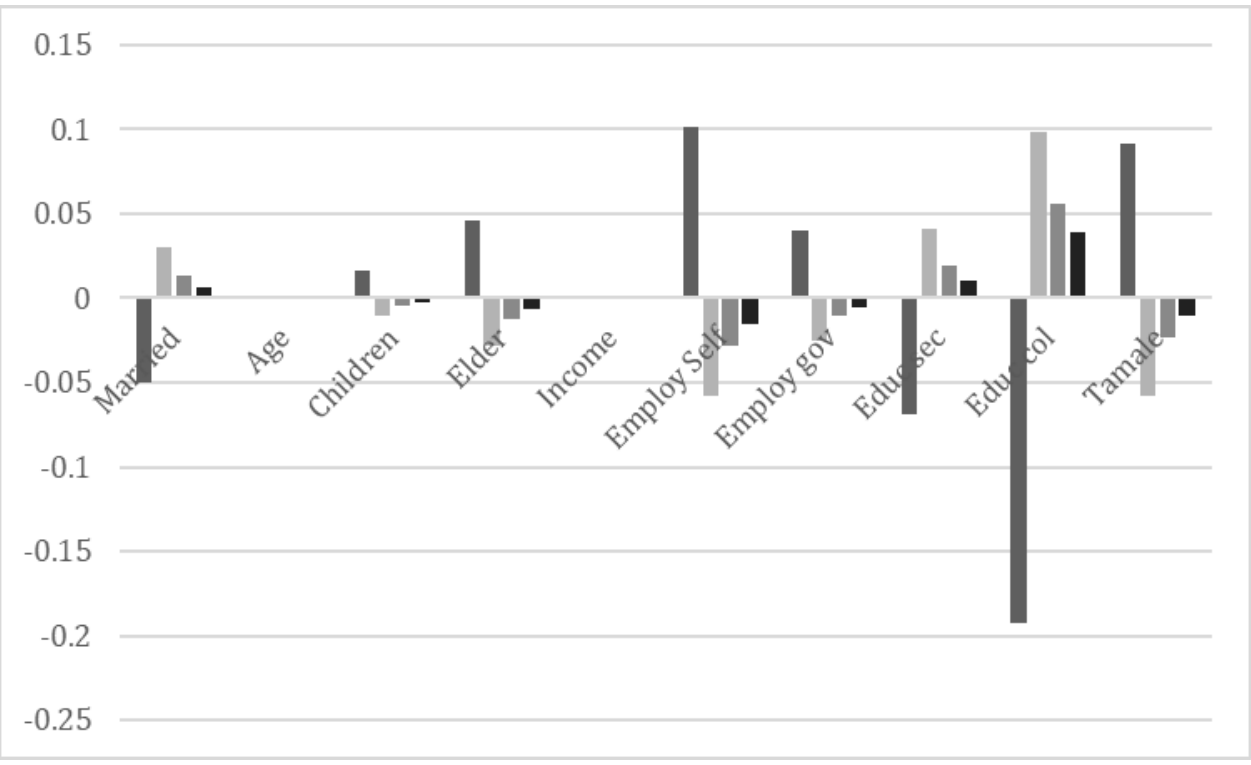

- Not at all $\square$ Seldom $\quad$ Often $\quad$ Very often

(d) electricity frequency use

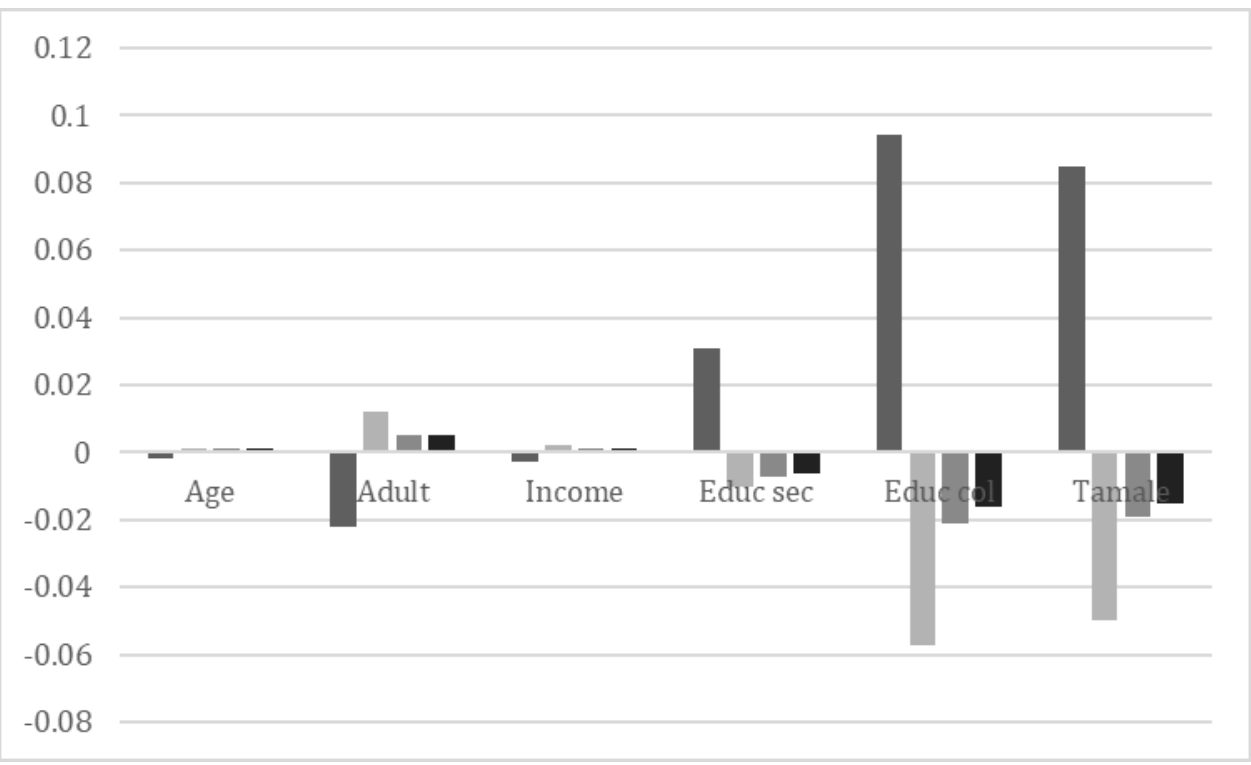

Not at all $\square$ Seldom $\quad$ Often $\quad$ Very often

(e) kerosene frequency use

Figure 2. Marginal effects of statistically significant factors on the probability of wood (a), charcoal (b), liquid gas (c), electricity (d), and kerosene (e) use frequency to cook the main meal of the day in urban households of Ghana. Note: $n=956$; full definitions of variables in Table 1. Source: Calculations based on the estimation results shown in Table 3.

\subsubsection{Charcoal}

The probability of using charcoal decreases in the frequency category "not at all" and "seldom" as the number of adults in the household increases (Figure 2b). Adults may prefer 
some dishes that are prepared using charcoal, possibly because of the detectable taste differences in the cooked meal. Income, government employment, and having education above elementary schooling appear to increase the probability of "not at all" or "seldom" using charcoal for cooking the main meal. The changes in probability were particularly high if a respondent worked for the government or received college education. For example, the latter had a $19.1 \%$ higher and $21 \%$ lower probability, respectively, of never cooking the main meal using charcoal or using it "very often" as compared to those having at most elementary education (Figure 2b). Differences also existed across location of the household with Tamale residents having an $11.6 \%$ higher probability of using charcoal "very often" in contrast to the residents of Accra.

\subsubsection{Liquid Gas}

Figure 2c displays a very different pattern of probability changes in liquid gas use frequency than the previous two fuel types. All socio-demographic variables and income displayed a similar effect on the probabilities associated with the four frequencies of using liquid gas in cooking. There is a substantial decrease in the probability of not using liquid gas at all in the case of marital status, income, government employment, and having more than elementary education (Figure 2, panel c). The specific change in the probabilities are $-8 \%,-2.4 \%,-15.4 \%,-15.4 \%$, and $-15.2 \%$, respectively. The same factors increased the probability of using liquid gas "very often" by $9.7 \%, 3 \%, 20.4 \%, 19.7 \%$, and 21.1\%, respectively (Figure 2c). The size of changes in the case of using liquid gas are the largest among all cooking fuels considered in the study. However, the residents of Tamale can be expected to have a $23.8 \%$ higher probability of not using liquid gas in cooking and a $26.3 \%$ lower probability of using it "very often" (Figure 2c) as compared to the surveyed Accra residents.

\subsubsection{Electricity}

Figure $2 d$, shows that the probability of using electricity for cooking the main meal of the day was affected by the largest number of variables. The probability of not using electricity to cook a meal increased if the number of teenage children (by $1.6 \%$ ) or the number of elderly (by 4.6\%) in the household increased as well (Figure 2d). Married respondents had a lower probability of not using electricity, $-5 \%$, but the probability increases in categories indicating use with varied frequency were rather small. A similar pattern was associated with income, but the changes in probability were negligible. Only a very large increase in income would increase the probability use of electricity by a noticeable amount.

Two variables indicating employment type changed the probability of using electricity in cooking in a similar way: increasing the probability of not using it by $10.1 \%$ by selfemployed respondents and by $4 \%$ if respondent was a government employee (Figure $2 \mathrm{~d}$ ). Secondary and college education decreased the probability of not using electricity by $6.9 \%$ and $19.3 \%$, respectively, but only marginally increased electricity use by 1 and $3.9 \%$, respectively. Tamale residents had a 9.2 higher probability of not using electricity for cooking and only $5.8 \%, 2.3 \%$, and $1 \%$ lower probability of using electricity with any meaningful frequency, respectively, as compared to residents of Accra.

\subsubsection{Kerosene}

Finally, changes in probability of using kerosene in cooking the main meal of the day were smallest among the five fuels, especially in the two highest frequency categories (Figure 2e). The effect on probability induced by changes in respondent age, number of adults in the household, and income were negligible or very small. Somewhat larger probability changes were associated with having secondary or college education. The probability of not using kerosene in cooking increased by $3.1 \%$ and $9.4 \%$ among respondents with secondary and college education, decreased by $1.8 \%$ and $5.7 \%$ the probability of "seldom" using kerosene, and decreased its more frequent use by very small or negligible 
amounts (Figure 2e). The changes in probability use of kerosene displayed a similar pattern and increased the probability by $8.5 \%$ of not using that fuel at all, while decreasing the probability use by $5 \%, 1.9 \%$, and $1.5 \%$, respectively, for the three remaining frequencies.

\section{Discussion}

Based on the results, the use of wood, the most traditional cooking fuel, has declined among urban households in Ghana, with only $20 \%$ of households still reporting its use in cooking their main meal. High income households are likely to abandon this traditional cooking fuel. This finding is consistent with the previous argument that traditional biomass still dominates low-income household energy needs [3]. Wood is relatively bulky and inconvenient to transport and store in a household. From the practical standpoint of use as a cooking fuel, wood requires constant attention when burning to assure even cooking, making it considerably less desired and, given an opportunity, many would likely choose other cooking fuels. Regarding occupation effects, government or civil employees have a significantly lower probability of cooking with wood with any frequency as compared to those not employed, students, and the retired. In addition, respondents with a secondary or college education tend to not use wood as their cooking fuel. Cooking with wood requires plenty of time spent on fuel collection and, later, requires constant attention while cooking, and highly educated households usually have a higher opportunity cost of time. Households in Tamale are more likely to use wood very often for cooking and this is undesirable because of the possible depletion of natural resources in the dry savannah zone.

Results of the study indicate that charcoal and liquid gas are the most widespread cooking fuels among the surveyed urban households in Ghana. About $87 \%$ of respondent households cook with charcoal, and $31.7 \%$ report using it very often. The preference for charcoal suggests that efforts associated with regulating tree harvesting and production and distribution of charcoal remain relevant. Charcoal made from different species burns differently, suggesting that specific tree varieties may be harvested at different rates. For example, in the area of Tamale in the dry savannah zone, one of the preferred species is the shea tree, which has other important economic uses and using it for charcoal production implies forgone future benefits.

Since charcoal continues to play a very prominent role as a cooking fuel in Ghana, the increased use of more efficient charcoal cooking stoves will generate instant gains in energy efficiency and decrease women and children's exposure to air pollution. Multiple designs of charcoal stoves are already in existence in Ghana. The likelihood of relying on charcoal for cooking significantly decreases for respondents with high incomes, government employment, and secondary or higher education. Compared with households in the capital, Tamale residents are more likely to cook with charcoal very often. Recalling the finding in relation to wood usage frequency above, it seems traditional fuels such as wood and charcoal continue to play a predominant role in cities in less developed areas of Ghana. Households with a large number of adult members are more likely to cook with charcoal very often. The frequent use may reflect preferences for dishes cooked using charcoal. Among such dishes are meat or fish grilled with the addition of groundnut cake (kulikulisim) that are less compatible with the use of other cooking fuels.

The percentage of respondents using liquid gas very often or often to cook the main meal of the day is $63.9 \%$. There is also a substantial share of respondents who never use liquid gas for cooking. The observed dichotomy in use reflects a broader problem of accessibility and stable supplies of liquid gas. The survey results show that Accra households are more likely than Tamale households to use liquid gas. Despite increasing supplies of liquid gas in recent years in Ghana, the demand outpaces the supply. The use of liquid gas in cooking would benefit a larger portion of the population than its use for transportation by improving indoor air quality. Past policies subsidized liquid gas prices but benefited mostly automobile transportation.

Households with high incomes have a larger probability of cooking with liquid gas very often than households with less income. The finding confirms the positive association 
between income growth and access to modern fuel [45]. The higher the education level, the more likely the household cooks with liquid gas very often. Moreover, households of married respondents are more likely to use liquid gas to cook very often. It is plausible that they are attracted by the convenience of this modern cooking fuel. Demand for convenience is driven by changes in lifestyle such as getting married as well as relatively high income and education levels, therefore, because of economic growth, the use of liquid gas is likely to increase in the future. Ghana has achieved remarkable growth in recent years and is classified as a low middle-income country by the World Bank.

Increasing incomes are found to be positively associated with the probability of cooking very often with electricity. Low-income households have a greater chance they never use electricity for cooking, likely due to the relatively high cost of electricity. Electricity is used mainly for lighting, radio, and TV, and it is widely unaffordable for cooking, especially among low-income households [3]. Besides the electricity cost, electric cooking appliances are relatively expensive and repair service scant. Both government and civil employees and the self-employed have a significantly lower probability of very often using electricity for cooking. Households with a secondary or college education tend to use electricity very often for cooking purposes. Accra-based households are more likely to cook very often with electricity than Tamale households, but not households located in Takoradi. Furthermore, married households cook with electricity very often compared to their counterparts. Age has a significantly positive but negligible probability effect on using electricity for cooking with any frequency. Households with a large number of children or elderly are less likely to cook with electricity.

Kerosene and electricity play a very limited role in cooking in Ghana. Because of the relative high costs of electricity, most households continue to use it for lighting (similarly to kerosene) but not cooking. Only $11.2 \%$ and $17.3 \%$ of the surveyed households report cooking with electricity or kerosene, respectively. Both are relatively efficient, easy to use and safe, but kerosene adulterated with diesel fuel generates soot discovered only during cooking. In addition, kerosene cooking equipment is not suitable for other cooking fuels. Results of the study indicate that older urban residents and households with many adults are more likely to cook at any frequency with kerosene. Education has a significantly negative effect on the frequency of kerosene use in cooking. Households in Tamale are less likely to cook with kerosene at any of the considered frequency levels compared to Accra-based households. The result is unexpected and potentially important for policies and regulations aimed at air quality improvement in Ghana's largest urban area.

\section{Conclusions}

Many previous studies explored household decisions in relation to cooking fuel choice but without the consideration of multiple fuel usage (see Section 2). This study contributes to the existing literature on cooking fuel choice and analysis of the frequency of using a specific fuel. As such, this study recognizes that households continue to use multiple fuels even if they have access to modern, clean cooking fuels. Such behavior has been continuing also in developed countries where, for example, grilling with charcoal is not uncommon and demand for charcoal continues [46]. Results lessen the expressed deficit of knowledge about household decision-making, especially choices regarding cooking fuel use, and allow formulation of policies to account for socio-demographic and economic factors [11].

Income is the major constraint in using modern fuels for cooking. High-income urban households choose to cook frequently with liquid gas or electricity, and are less likely to use traditional fuel such as wood or charcoal. With the expansion of liquid petroleum gas distribution, access to that type of fuel will be eased [10]. Energy subsidies to low-income households could enhance their use of efficient cooking fuels. However, as users experience unpredictable disruptions of supplies they are forced to continue to use alternative cooking fuels, while specific preferences for a particular fuel type encourage the practice of fuel stacking. Consequently, urban households in major Ghana cities still rely on an energy mix 
that includes modern and traditional cooking fuels. Therefore, improving the efficiency of traditional cooking stoves remains relevant given the household energy mix [47].

Employment type matters in the frequency use of various cooking fuels. Households with regular and stable incomes, e.g., government or civil employees, are more likely to cook with liquid gas, while less likely to use either wood or charcoal frequently. It indicates that households lacking or having irregular income including the unemployed, students, or the retired are exposed to the effects of cooking fuels that are detrimental to human health and lower environmental quality. Higher education of respondents has been found to promote the transition from biomass fuels to modern cooking fuels. Such households are more likely to use liquid gas or electricity and are less likely to use wood, charcoal, or kerosene. Thus, creating training and education opportunities is essential to encourage households to move up the "energy ladder." This is an important result because it illustrates that education can offset effects of income at least to some extent.

Furthermore, cooking fuel usage frequency is significantly associated with demographic factors. Urban households of married respondents cook with liquid gas and electricity very often. Age has a significant positive effect on cooking with electricity and kerosene frequently. However, the number of adults (19-60 years of age) significantly increases the usage frequency of less desirable (from a health and pollution standpoint) cooking fuels including wood, charcoal, and kerosene. Households with a large number of elders (61 years or older) are less likely to cook with electricity plausibly because of cooking habits and lack of experience in using electric stoves. In households with elderly members, the daily chore of cooking may be delegated to the elders, charging them with the choice of cooking method and fuel. Educating older consumers could accelerate energy transition, but will require an approach that is suitable for that demographic segment.

Important spatial differences are confirmed by the current study in the use of fuels to cook the main meal of the day. Such within-the-country variations have been ignored in earlier studies. Compared with residents of the capital city, respondents from households in less developed areas, such as Tamale in the Northern Region, still heavily rely on wood and charcoal. They are less likely to often use modern fuels such as liquid gas or electricity, supporting a program that would assist households to alter the use of cooking fuels in the savannah zone.

The specifics of policies formulating and implementing relevant energy-use programs need to consider not simply the choice of the cooking fuel but the current frequency use of cooking fuels in the context of the profiles shown in Table 3 and the result of the estimated five-equation system. The fuel choice and use frequency varies across urban households and those with more education or income tend to use fuels that generate fewer health and environmental hazards. The current study shows that the continuing use of traditional inefficient and polluting cooking fuels will moderate as household income increases. The Ghanaian economy has been growing in recent decades, albeit unevenly [48], creating conditions that are weakening the demand for traditional cooking fuels. Energy aid and promotion programs need an additional special focus on those from unmarried households with a number of elders and children. Air pollution from traditional cooking fuels has been linked to an array of diseases [49,50]. Moreover, urban households in less developed areas, such as the Northern Region, create demand for wood and charcoal in an area that is more susceptible to environmental damage although the national use of fuelwood may remain in balance. The reduction of regional disparities requires expansion of the domestic modern energy supply system and adjustments in national policy to account for regional specificity in cooking fuel use, recognizing that energy for cooking represents a relatively large share of northern urban household energy expenditures.

Author Contributions: T.M.: conceptualization, methodology, writing, original data preparation, formal analysis, validation; W.J.F.: conceptualization, writing, review and editing, project administration, funding acquisition; D.B.S.: sample preparation, survey organization, data collection, M.C.: review and editing, A.V.A.R.: review and editing. All authors have read and agreed to the published version of the manuscript. 
Funding: The data used in this study were collected under the grant "Enhancing the peanut value chain, from processing to marketing peanut and peanut products," USAID RF W-710-023.

Institutional Review Board Statement: Ethical review and approval were waived for this study due to the conventional content of the questionnaire.

Informed Consent Statement: Not applicable.

Data Availability Statement: Data available from the authors upon request.

Acknowledgments: The authors acknowledge financial support from Peanut Innovation and Mycotoxin Lab/USAID for the collection of the data used in this study through the grant "Enhancing the peanut value chain, from processing to marketing peanut and peanut products," USAID RF W-710-023.

Conflicts of Interest: The authors declare no conflict of interest.

\section{References}

1. Heltberg, R. Fuel switching: Evidence from eight developing countries. Energy Econ. 2004, 26, 869-887. [CrossRef]

2. Choudhuri, P.; Desai, S. Gender inequalities and household fuel choice in India. J. Clean. Prod. 2020, 265, 121487. [CrossRef]

3. Prasad, G. Improving access to energy in sub-Saharan Africa. Curr. Opin. Environ. Sustain. 2011, 3, 248-253. [CrossRef]

4. Brew-Hammond, A. Energy access in Africa: Challenges ahead. Energy Policy 2010, 38, 2291-2301. [CrossRef]

5. Ensure Access to Affordable, Reliable, Sustainable and Modern Energy for All. 2020. Available online: https://unstats.un.org/ sdgs/report/2019/goal-07/ (accessed on 8 December 2020).

6. Nabukalu, C.; Gieré, R. Charcoal as an Energy Resource: Global Trade, Production and Socioeconomic Practices Observed in Uganda. Resources 2019, 8, 183. [CrossRef]

7. IEA. World Energy Outlook 2006; International Energy Agency: Paris, France, 2006.

8. Food and Agricultural Organization. Forestry Production and Trade; FAO: Rome, Italy, 2019; Volume 2019.

9. Collins, B. Africa's \$40B Market for Cooking Fuel Is Being Cleaned Up: Q\&A. 2019. Available online: https://about.bnef.com/ blog/africas-40b-market-cooking-fuel-cleaned-qa/ (accessed on 9 December 2020).

10. Dalaba, M.; Alirigia, R.; Mesenbring, E.; Coffey, E.; Brown, Z.; Hannigan, M.; Wiedinmyer, C.; Oduro, A.; Dickinson, K.L. Liquified Petroleum Gas (LPG) Supply and Demand for Cooking in Northern Ghana. EcoHealth 2018, 15, 716-728. [CrossRef]

11. Foell, W.; Pachauri, S.; Spreng, D.; Zerriffi, H. Household cooking fuels and technologies in developing economies. Energy Policy 2011, 39, 7487-7496. [CrossRef]

12. Lacey, F.G.; Henze, D.K.; Lee, C.J.; van Donkelaar, A.; Martin, R.V. Transient climate and ambient health impacts due to national solid fuel cookstove emissions. Proc. Natl. Acad. Sci. USA 2017, 114, 1269-1274. [CrossRef]

13. WHO. Indoor Air Pollution and Health. 2011. Available online: http://www.who.int/mediacenter/factsheetts/fs292/en (accessed on 11 January 2013).

14. Jetter, J.J.; Kariher, P. Solid-fuel household cook stoves: Characterization of performance and emissions. Biomass Bioenergy 2009, 33, 294-305. [CrossRef]

15. Lim, S.S.; Vos, T.; Flaxman, A.D.; Danaei, G.; Shibuya, K.; Adair-Rohani, H.; AlMazroa, M.A.; Amann, M.; Anderson, H.R.; Andrews, K.G.; et al. A comparative risk assessment of burden of disease and injury attributable to 67 risk factors and risk factor clusters in 21 regions, 1990-2010, a systematic analysis for the Global Burden of Disease Study 2010. Lancet 2012, 380, 2224-2260. [CrossRef]

16. National Energy Policy; Ministry of Energy: Accra, Ghana, 2010.

17. Yiridoe, E.K.; Nanang, D.M. An Econometric Analysis of the Causes of Tropical Deforestation: Ghana; American Agricultural Economics Association: Chicago, IL, USA, 2001.

18. Anang, B.T.; Kkuriba, M.A.; Alerigesane, A.A. Charcoal production in Gushegu District, Northern Region, Ghana: Lessons for sustainable forest management. Int. J. Environ. Sci. 2011, 1, 1944-1953.

19. World Bank. The Little Green Data Book 2017; World Bank: Washington, DC, USA, 2017. [CrossRef]

20. Edwards, R.D.; Smith, K.R.; Zhang, J.; Ma, Y. Implications of changes in household stoves and fuel use in China. Energy Policy 2004, 32, 395-411. [CrossRef]

21. Bond, T.C.; Sun, H.L. Can reducing black carbon emissions counteract global warming? Environ. Sci. Technol. 2005, 39, 5921-5926. [CrossRef] [PubMed]

22. Rehfuess, E.; Mehta, S.; Prüss-Üstün, A. Assessing Household Solid Fuel Use: Multiple Implications for the Millennium Development Goals. Environ. Health Perspect. 2006, 114, 373-378. [CrossRef] [PubMed]

23. Blackburn-Dwyer, B. The Top 10 Fastest Growing Cities in The World. 2016. Available online: https:/ /www.globalcitizen.org/ en/content/world-fastest-growing-cities/?template=next (accessed on 18 June 2021).

24. Carrión, D.; Dwommoh, R.; Tawiah, T.; Agyei, O.; Agbokey, F.; Twumasi, M.; Mujtaba, M.; Jack, D.; Asante, K.P. Enhancing LPG adoption in Ghana (ELAG): A factorial cluster-randomized controlled trial to Enhance LPG Adoption \& Sustained use. BMC Public Health 2018, 18, 1-11. [CrossRef] 
25. Brew-Hammond, A.; Kemausuor, F. Energy for all in Africa-to be or not to be?! Curr. Opin. Environ. Sustain. 2009, 1, 83-88. [CrossRef]

26. Mensah, J.T.; Adu, G. An empirical analysis of household energy choice in Ghana. Renew. Sustain. Energy Rev. 2015, 51, 1402-1411. [CrossRef]

27. Louw, K.; Conradie, B.; Howells, M.; Dekenah, M. Determinants of electricity demand for newly electrified low-income African households. Energy Policy 2008, 36, 2812-2818. [CrossRef]

28. Ouedraogo, B. Household energy preferences for cooking in urban Ouagadougou, Burkina Faso. Energy Policy 2006, 34, 3787-3795. [CrossRef]

29. Pope, D.; Bruce, N.; Higgerson, J.; Hyseni, L.; Stanistreet, D.; Mbatchou, B.; Puzzolo, E. Household Determinants of Liquified Petroleum Gas (LPG) as a Cooking Fuel in SW Cameroon. EcoHealth 2018, 15, 729-743. [CrossRef]

30. Sharma, B.P. Household Fuel Transition and Determinants of Firewood Demand in Nepal. Econ. J. Dev. Issues 2019, 83-95. [CrossRef]

31. Giri, M.; Goswami, B. Determinants of Household's Choice of Fuel for Cooking in Developing Countries: Evidence from Nepal. J. Dev. Policy Pract. 2018, 3, 137-154. [CrossRef]

32. Acharya, B.; Marhold, K. Determinants of household energy use and fuel switching behavior in Nepal. Energy 2019, 169, 1132-1138. [CrossRef]

33. Paudel, U.; Khatri, U.; Pant, K.P. Understanding the determinants of household cooking fuel choice in Afghanistan: A multinomial logit estimation. Energy 2018, 156, 55-62. [CrossRef]

34. Wickramasinghe, A. Energy access and transition to cleaner cooking fuels and technologies in Sri Lanka: Issues and policy limitations. Energy Policy 2011, 39, 7567-7574. [CrossRef]

35. Clemens, H.; Bailis, R.; Nyambane, A.; Ndung'U, V. Africa Biogas Partnership Program: A review of clean cooking implementation through market development in East Africa. Energy Sustain. Dev. 2018, 46, 23-31. [CrossRef] [PubMed]

36. Vigolo, V.; Sallaku, R.; Testa, F. Drivers and Barriers to Clean Cooking: A Systematic Literature Review from a Consumer Behavior Perspective. Sustainability 2018, 10, 4322. [CrossRef]

37. Prasad, G. Energy sector reform, energy transitions and the poor in Africa. Energy Policy 2008, 36, 2806-2811. [CrossRef]

38. World Bank Group. Rising through Cities in Ghana: Ghana Urbanization Review Overview Report; World Bank: Washington, DC, USA, 2015. Available online: https:/ / openknowledge.worldbank.org/handle/10986/22020 (accessed on 23 April 2021).

39. Sajaia, Z. Maximum Likelihood Estimation of a Bivariate Ordered Probit Model: Implementation and Monte Carlo Simulations. Stata J. 2008, 4, 1-18. Available online: http:/ / www.ecreee.org/sites/default/files/event-att/ghana_national_strategies_for_ cooking_fuels._burkina_2013_1.pdf (accessed on 6 October 2014).

40. Barnes, D.F.; Qian, L. Urban Interfuel Substitution, Energy Use, and Equity in Developing Countries; Series Papers 53; World Bank, Industry and Energy Department: Washington, DC, USA, 1992.

41. Leach, G. The energy transition. Energy Policy 1992, 20, 116-123. [CrossRef]

42. Zulu, L.C.; Richardson, R. Charcoal, livelihoods, and poverty reduction: Evidence from sub-Saharan Africa. Energy Sustain. Dev. 2013, 17, 127-137. [CrossRef]

43. Ghana Web. 2013. Available online: http://www.ghanaweb.com/GhanaHomePage/economy/forex.php (accessed on 12 January 2013).

44. Ahiotoku-Togoba, W. National cooking energy strategies-lessons from Ghana. In Proceedings of the WACCA Workshop, Ouagadougou, Burkina Faso, 23-25 April 2013.

45. Sokona, Y.; Mulugetta, Y.; Gujba, H. Widening energy access in Africa: Towards energy transition. Energy Policy 2012, 47, 3-10. [CrossRef]

46. Heimann, J.; Dresch, A.R.; Almeida, A.N. The demand by the United States of America for the Brazilian charcoal. Ciência Florest. 2015, 25, 437-445.

47. Boafo-Mensah, G.; Ampomah-Benefo, K.; Animpong, M.A.B.; Oduro, W.O.; Kotey, E.N.; Akufo-Kumi, K.; Laryea, G.N. Thermal efficiency of charcoal fired cookstoves in Ghana. GARJETI 2013, 2, 102-110.

48. GDP per Capita (Current US\$)—Ghana. 2021. Available online: https://data.worldbank.org/indicator/NY.GDP.PCAP.CD? locations $=$ GS (accessed on 20 July 2021).

49. Kim, K.-H.; Jahan, S.A.; Kabir, E. A review of diseases associated with household air pollution due to the use of biomass fuels. J. Hazard. Mater. 2011, 192, 425-431. [CrossRef]

50. Van Vliet, E.D.S.; Asante, K.; Jack, D.W.; Kinney, P.L.; Whyatt, R.M.; Chillrud, S.N.; Abokyi, L.; Zandoh, C.; Owusu-Agyei, S. Personal exposures to fine particulate matter and black carbon in households cooking with biomass fuels in rural Ghana. Environ. Res. 2013, 127, 40-48. [CrossRef] [PubMed] 